Journal of Nutrition College, Volume 4, Nomor 2, Tahun 2015, Halaman 308-313

Online di : http://ejournal-sl.undip.ac.id/index.php/jnc

\title{
PENGARUH PEMBERIAN SEDUHAN DAUN KELOR (MORINGA OLEIFERA LAM) TERHADAP JUMLAH LEUKOSIT TIKUS PUTIH (Ratus novergicus) JANTAN
}

\author{
Alnur Aulia A, Aryu Candra $K^{*}$ \\ Program Studi Ilmu Gizi Fakultas Kedokteran Universitas Diponegoro \\ Jl.Dr.Sutomo No.18, Semarang, Telp (024) 8453708, Email : gizifk@undip.ac.id
}

\begin{abstract}
Background: Moringa leaves (Moringa oleifera Lam) have anti-inflammatory effect, vitamin, mineral, and quercetin. Hyperuricemia can lead an inflammatory response and increase total leukocyte.

Objective: To analyze the effect of steeping moringa leaves with a dose of $3.27 \mathrm{~g} / \mathrm{kgBW}$ to total leukocyte in rats

Method: True experimental research with pre-posttest randomized control group design in 12 wistar rats aged 8-12 weeks were divided into 2 groups randomly. The control and treatment group were given goat brain $2 \mathrm{~g} / \mathrm{rat} / \mathrm{day}$ for 8 days. After that control group were given standard feed and aquades and treatment group were given 3,6 ml stepping moringa leaves for 14 days. Blood tests done 3 times, before and after administration of goat brain and after giving steeping moringa leaves.

Result: Uric acid levels significantly decrease in the control group $(p=0.002)$, but no significant in the treatment group $(p=0.086)$ after administration of goat brain. Total leukocytes significantly increase in the control group $(p=0.005)$ and treatment $(p=0.015)$ after administration of goat brain. There was no correlation between uric acid and total leukocyte $(p=0,65)$. Total leukocyte significantly decrease in control $(p=0.004)$ and treatment group $(p=0.008)$ after administration of steeping moringa leaves. Treatment group have a greater decrease.
\end{abstract}

Conclusion: Steeping moringa leaves with a dose $3.27 \mathrm{~g} / \mathrm{kgBW}$ for 14 days can reduce total leukocyte of rats significantly.

Keyword: Hyperuricemia, Inflammation, Leukocyte, Quercetin

\section{ABSTRAK}

Latar belakang: Daun kelor (Moringa oleifera Lam) dilaporkan memiliki sifat antiinflamasi karena mengandung vitamin, mineral, serta kuersetin. Hiperurisemia dapat memicu respon inflamasi yang salah satunya ditandai dengan meningkatnya jumlah leukosit.

Tujuan:Menganalisis pengaruh pemberian seduhan daun kelor dengan dosis 3,27 g/kgBB terhadap jumlah leukosit tikus wistar jantan.

Metode:Penelitian true experimental dengan pre-post test randomized control group design pada 12 tikus wistar jantan usia 8-12 minggu yang dibagi menjadi 2 kelompok secara acak masing-masing 6 ekor. Kelompok K (Kontrol) dan P (Perlakuan) diberi otak kambing 2g/ekor/hari selama 8 hari. Setelah itu kontrol diberi pakan standar dan akuades, sedangkan perlakuan diberi 3,6 ml seduhan daun kelor selama 14 hari. Pemeriksaan darah dilakukan sebanyak 3 kali, yaitu sebelum dan sesudah pemberian otak kambing dan sesudah pemberian seduhan daun kelor.

Hasil: Terdapat penurunan kadar asam urat yang signifikan pada kelompok kontrol (p=0,002), namun tidak terdapat perbedaan signifikan pada kelompok perlakuan $(p=0,086)$ setelah pemberian otak kambing. Perbedaan signifikan terjadi pada jumlah leukosit pada kelompok kontrol $(p=0,005)$ dan perlakuan $(p=0,015)$ setelah pemberian otak kambing. Hal ini menunjukkan tidak terdapat hubungan antara kadar asam urat dan jumlah leukosit $(p=0,65)$. Terdapat perbedaan signifikan pada jumlah leukosit kelompok perlakuan $(p=0,008)$ maupun kontrol $(p=0,004)$ setelah pemberian seduhan daun kelor, namun penurunan rerata lebih besar pada kelompok perlakuan.

Kesimpulan:Pemberian seduhan daun kelor dengan dosis 3,27 g/kgBB selama 14 hari dapat menurunkan jumlah leukosit tikus secara signifikan

Kata kunci: Hiperurisemia, Inflamasi, Leukosit, Kuersetin

\section{PENDAHULUAN}

Leukosit mempunyai peranan dalam pertahanan seluler dan humoral organisme terhadap zat-zat asingan. ${ }^{1,2}$ Leukosit bekerja sama dengan imunoglobulin dan komplemen sebagai respon imun. ${ }^{1}$ Neutrofil, eosinofil, basofil, dan monosit adalah jenis-jenis leukosit yang bersifat fagosit, mereka menelan dan menghancurkan patogen dan sisa-sisa sel. ${ }^{1}$ Peningkatan leukosit menunjukkan aktivasi pertahanan dan sistem kekebalan tubuh dan menunjukkan ada peradangan pada jaringan. ${ }^{3}$

Leukositosis adalah peningkatan jumlah leukosit dalam sirkulasi hingga melebihi nilai normal. ${ }^{1,3}$ Hal ini paling sering disebabkan oleh infeksi atau proses inflamasi. ${ }^{3}$ Akumulasi leukosit di lokasi infeksi dengan pelebaran pembuluh darah dan meningkatnya kebocoran cairan dan protein dalam jaringan disebut inflamasi. ${ }^{4}$ Inflamasi dapat terjadi karena berbagai hal salah satunya arthritis. ${ }^{3,5}$

\footnotetext{
${ }^{*}$ Penulis Penanggungjawab
} 
Faktor resiko terhadap kejadian arthritis adalah keadaan hiperurisemia. ${ }^{6}$ Hiperurisemia adalah peningkatan kadar asam urat darah di atas normal. ${ }^{6}$ Peningkatan asam urat berhubungan positif dengan penanda inflamasi seperti leukosit, ${ }^{5}$ c-reactive protein (CRP), interleukin-6 (IL-6), interleukin-1 receptors antagonist (IL-1ra), soluble interleukin-6 receptor (sIL-6r), interleukin-18 (IL-18), dan tumor necrosis factor- $\alpha$ (TNF- $\alpha){ }^{7,8,9}$ Kristal monosodium urat akan memicu respon fagositik oleh leukosit dengan menstimulasi sel makrofag untuk memproduksi sitokin-sitokin yang akan memacu penarikan leukosit ke daerah deposit kristal monosodium urat sehingga leukosit memakan kristal-kristal urat dan memicu mekanisme respons inflamasi lainnya. ${ }^{6,10}$

Leukosit mempunyai hubungan dengan mekanisme kejadian penyakit iskemik vaskular akut dan kronis. ${ }^{11}$ Jumlah leukosit yang lebih tinggi juga dikaitkan dengan resistensi terhadap trombolisis, peningkatan beban trombus, gangguan mikrovaskular perfusi, serta menunjukkan kecenderungan yang kuat terhadap hubungan independen dengan perkembangan gagal jantung kongestif dan kematian. ${ }^{11}$ Akumulasi dan perekrutan leukosit yang terus-menerus terkait dengan pembentukan plak. ${ }^{12}$ Plak ini rentan pecah, menyebabkan trombosis, infark miokard atau stroke. ${ }^{12}$ Penurunan jumlah leukosit diharapkan dapat meminimalkan risiko tersebut. ${ }^{11}$

Tanaman kelor dapat tumbuh dengan baik dan dapat bertahan hidup dalam kondisi iklim yang keras termasuk tanah yang buruk tanpa banyak terpengaruh oleh kekeringan..$^{13}$ Berbagai bagian dari tanaman ini seperti daun, akar, biji, kulit kayu, buah, dan bunga bertindak sebagai stimulan jantung dan peredaran darah, mengobati rematik, memiliki antitumor, antipiretik, antiepilepsi, antiinfeksi, antiinflamasi, antiulcer, diuretik, antihipertensi, penurun kolesterol, antioksidan, antidiabetes, hepatoprotektif, antibakteri dan antijamur. ${ }^{14,15,16}$ Daun kelor (Moringa oleifera) mengandung vitamin A, C, E, B6, thiamin, riboflavin, niacin, dan folate. ${ }^{14,16,17}$ Daun kelor juga kaya akan mineral seperti $\mathrm{Ca}, \mathrm{P}, \mathrm{Na}, \mathrm{K}, \mathrm{Fe}, \mathrm{Mg}, \mathrm{Zn}$, dan $\mathrm{Cu}^{14,16,17}$ Selain itu, daun kelor juga mengandung asam amino, zeatin, $\beta$-sitosterol, asam caffeoylquinic, kuersetin dan kaempferol. ${ }^{14,16}$

Pemberian teh daun kelor selama 7 hari pada tikus menunjukan sifat antiinflamasi pada radang paru-paru akut. ${ }^{18}$ Bubuk daun kelor yang diberikan pada tikus selama 4 hari juga efektif dalam pengelolaan anemia. ${ }^{19}$ Ekstrak metanol daun kelor efektif dalam pengobatan rheumatoid arthritis. ${ }^{5}$ Tikus yang dibuat arthritis menunjukkan penurunan sel darah merah, hemoglobin, dan peningkatan leukosit. ${ }^{5}$ Setelah pemberian ekstrak metanol daun kelor menunjukan perbaikan yang signifikan dengan peningkatan sel darah merah, hemoglobin, dan penurunan leukosit. ${ }^{5}$

Pemberian kuersetin dengan dosis $10 \mathrm{mg} / \mathrm{kg}$ pada tikus yang diinduksi karagenan menunujukkan penurunan jumlah protein, jumlah sel, dan TNF $\alpha .{ }^{20}$ Pemberian kuersetin selama 2 minggu pada tikus steatohepatitis menunjukkan IL-6 dan TNF $\alpha$ yang lebih rendah. ${ }^{21}$ Penelitian lain juga menunjukkan kuersetin menurunkan kadar asam urat plasma, IL$1 \beta$, dan IL-18 pada tikus dengan gangguan ginjal yang diinduksi streptozotocin. ${ }^{22}$ Suplementasi vitamin $\mathrm{C}$ dapat menurunkan leukosit pada tikus yang diinduksi deltamethrin. ${ }^{23}$ Kuersetin $10 \mathrm{mg} / \mathrm{kg}$ berat badan dapat diperoleh dari $11,1 \mathrm{~g}$ daun kelor segar.

\section{METODE PENELITIAN}

Penelitian ini merupakan penelitian true eksperimental dengan rancangan pre-post test randomized control group design. Variabel bebas dalam penelitian ini adalah pemberian seduhan daun kelor, variabel antara adalah kadar asam urat, dan variabel terikat adalah jumlah leukosit. Penelitian dilakukan di laboratorium Biologi Fakultas Matematika dan Ilmu Pengetahuan Alam Universitas Negeri Semarang.

Sampel dari penelitian ini adalah tikus wistar jantan usia 8-12 minggu dengan berat badan 150-180 gram yang didapat dari laboratorium biologi FMIPA UNNES. Besar sampel ditentukan berdasarkan ketentuan WHO, yaitu minimal 5 ekor kemudian ditambah faktor resiko drop out sebesar $10 \%$, sehingga didapatkan 6 ekor tikus setiap kelompok. Tikus diambil menggunakan metode simple random sampling dan dibagi dalam 2 kelompok yaitu kelompok K (kontrol) dan kelompok P (perlakuan).

Masa adaptasi tikus berlangsung selama 7 hari. Kemudian dilanjutkan dengan pemberian otak kambing sebanyak 2 gram/ekor yang dilakukan selama 8 hari pada kedua kelompok. Setelah itu kelompok kontrol hanya mendapat pakan standar dan aquades, sedangkan kelompok perlakuan mendapatkan pakan standar dan seduhan daun kelor 3,6 ml/ekor selama 14 hari. Pemberian otak kambing dan seduhan daun kelor diberikan secara sonde.

Pembuatan seduhan daun kelor dilakukan dengan cara mengeringkan daun kelor segar dalam suhu ruang selama 4 hari, lalu dihaluskan. Daun kelor yang sudah halus diseduh menggunakan air lalu disaring. Dosis kuersetin yang diperlukan 
adalah $10 \mathrm{mg} / \mathrm{kgBB}$ yang bisa didapatkan dari 11,1 gram daun kelor segar. Daun kelor segar sebanyak 11,1 gram setelah mengalami pengeringan menjadi 3,75 gram. Sehingga didapatkan dosis 0,75 gram $/ 200 \mathrm{gBB}$ yang dilarutkan dalam $3,6 \mathrm{ml}$ aquades.

Sampel darah diambil sebanyak 3 kali, yaitu sebelum dan sesudah pemberian otak kambing serta sesudah pemberian seduhan daun kelor. Kadar asam urat darah diperiksa menggunakan spektrofotometri. Pengukuran jumlah leukosit dilakukan dengan cara memasukkan darah ke dalam pipet leukosit yang mengandung EDTA (Ethylene Diamine Tetra Acetic Acid) dan larutan Turk kemudian dihitung menggunakan kamar hitung (neubauer) di bawah mikroskop dengan pembesaran 100x. Hasil laboratorium akan diuji menggunakan uji beda untuk melihat perbedaan antara kelompok kontrol dan perlakuan serta sebelum dan sesudah perlakuan.
Data yang telah didapat diolah menggunakan komputer. Pertama data diuji normalitasnya dengan uji Shapiro-Wilk karena $\mathrm{n}<50$. Perbedaan kadar asam urat dan jumlah leukosit antara kelompok kontrol dan perlakuan duji dengan independent $t$ test karena data berdistribusi normal. Perbedaan jumlah leukosit sebelum dan sesudah perlakuan pada masing-masing kelompok diuji dengan dependent paired t test.

\section{HASIL PENELITIAN}

Keseluruhan sampel memenuhi syarat penelitian. Total sampel berjumlah 12 ekor tikus wistar jantan berusia 8-12 minggu dengan berat badan 150-180 gram yang diperoleh dari laboratorium biologi Fakultas MIPA UNNES. Populasi sampel kemudian dibagi secara random sampling menjadi 2 kelompok yaitu $\mathrm{K}$ dan $\mathrm{P}$ yang masing-masing berjumlah 6 ekor.

Tabel 1. Kadar Asam Urat Sebelum dan Sesudah Pemberian Otak Kambing

\begin{tabular}{cccccc}
\hline Kel & $\mathrm{n}$ & Sebelum $\left(/ \mathrm{mm}^{3} \pm\right.$ s.b $)$ & Sesudah $\left(/ \mathrm{mm}^{3} \pm\right.$ s.b $)$ & $\Delta$ & $p$ \\
\hline $\mathrm{K}$ & 6 & $3,49 \pm 0,39$ & $2,95 \pm 0,54$ & $(-) 0,54 \pm 0,21$ & $0,002^{\mathrm{b}}$ \\
$\mathrm{P}$ & 6 & $1,63 \pm 0,57$ & $2.46 \pm 0,47$ & $(+) 0,83 \pm 0,95$ & $0,086^{\mathrm{b}}$ \\
$p$ & 12 & $0,000^{\mathrm{a}}$ & $0,131^{\mathrm{a}}$ & & \\
\hline
\end{tabular}

a. Independent t test

b. Dependent paired t test

Tabel 1 menunjukkan hasil uji beda tidak berpasangan kadar asam urat sebelum pemberian otak kambing menunjukkan perbedaan yang signifikan $(p=0,000)$ dengan beda rerata yang cukup jauh antara kelompok kontrol dan perlakuan. Sedangkan setelah pemberian otak kambing menunjukkan tidak ada perbedaan $(p=0,131)$.
Hasil uji beda berpasangan pada kelompok kontrol setelah pemberian otak kambing menunjukkan perbedaan yang signifikan $(p=0,002)$ berupa penurunan kadar asam urat. Sedangkan pada kelompok perlakuan tidak terdapat perbedaan yang signifikan $(p=0,086)$ walaupun mengalami peningkatan rerata.

Tabel 2. Jumlah Leukosit Sebelum dan Sesudah Pemberian Otak Kambing

\begin{tabular}{cccccc}
\hline Kel & $\mathrm{n}$ & Sebelum $\left(/ \mathrm{mm}^{3} \pm \mathrm{s.b}\right)$ & Sesudah $\left(/ \mathrm{mm}^{3} \pm \mathrm{s} . \mathrm{b}\right)$ & $\Delta$ & $p$ \\
\hline $\mathrm{K}$ & 6 & $6208,33 \pm 730,35$ & $7004,17 \pm 910,00$ & $(+) 795,83 \pm 405,41$ & $0,005^{\mathrm{b}}$ \\
$\mathrm{P}$ & 6 & $6608,33 \pm 445,44$ & $7108,33 \pm 625,97$ & $(+) 595,83 \pm 283,03$ & $0,015^{\mathrm{b}}$ \\
$p$ & 12 & $0,279^{\mathrm{a}}$ & $0,821^{\mathrm{a}}$ & & \\
\hline a. & Independent t test & & & \\
$\mathrm{b}$. & Dependent paired t test & & &
\end{tabular}

Tabel 2 menunjukkan hasil uji beda tidak berpasangan jumlah leukosit antara kelompok kontrol dan perlakuan sebelum pemberian otak kambing menunjukkan tidak ada perbedaan $(p=$ 0,279 ) begitu juga dengan sesudah pemberian otak kambing $(p=0,279)$. Hasil uji beda berpasangan sebelum dan sesudah pemberian otak kambing menunjukkan perbedaan yang signifikan pada kelompok kontrol $(p=0,005)$ dan perlakuan $(p=$ $0,015)$. Berdasarkan hasil uji hubungan antara kadar asam urat dan jumlah leukosit setelah pemberian otak kambing menunjukkan tidak ada hubungan yang bermakna $(p=0,65)$. 
Tabel 3. Jumlah Leukosit Sebelum dan Sesudah Pemberian Seduhan Daun Kelor

\begin{tabular}{cccccc}
\hline Kel & $\mathrm{n}$ & Sebelum $\left(/ \mathrm{mm}^{3} \pm \mathrm{s} . \mathrm{b}\right)$ & Sesudah $\left(/ \mathrm{mm}^{3} \pm \mathrm{s.b}\right)$ & $\Delta$ & $p$ \\
\hline $\mathrm{K}$ & 6 & $7004,17 \pm 910,00$ & $6408,33 \pm 811,12$ & $(-) 500,00 \pm 303,73$ & $0,004^{\mathrm{b}}$ \\
$\mathrm{P}$ & 6 & $7108,33 \pm 625,97$ & $6442,67 \pm 489,81$ & $(-) 666,67 \pm 379,36$ & $0,008^{\mathrm{b}}$ \\
$p$ & 12 & $0,821^{\mathrm{a}}$ & $0,933^{\mathrm{a}}$ & & \\
\hline a. & Independent t test & & & \\
b. & Dependent paired t test & & &
\end{tabular}

Tabel 3 menunjukkan hasil uji beda tidak berpasangan jumlah leukosit antara kelompok kontrol dan perlakuan sebelum pemberian seduhan daun kelor menunjukkan tidak ada perbedaan $(p=$ 0,821 ), begitu juga dengan sesudah pemberian seduhan daun kelor $(p=0,933)$. Hasil uji beda berpasangan sebelum dan sesudah pemberian seduhan daun kelor menunjukkan perbedaan yang signifikan pada kelompok kontrol $(p=0,004)$ dan perlakuan $(p=0,008)$. Namun penurunan rerata lebih besar pada kelompok perlakuan dibandingkan kelompok kontrol.

\section{PEMBAHASAN}

Pemberian otak kambing diharapkan dapat meningkatkan kadar asam urat pada tikus. Otak kambing merupakan makanan tinggi purin. Hasil akhir katabolisme purin adalah asam urat. Kadar asam urat setelah pemberian otak kambing pada kelompok kontrol lebih tinggi jika dibandingkan dengan kelompok perlakuan dengan beda signifikan meski masih dalam nilai normal. Hal ini diduga karena perbedaan metabolisme pada masing-masing tikus. Selain itu juga bisa dikarenakan reagen yang terkontaminasi. ${ }^{24}$ Kadar asam urat setelah pemberian otak kambing pada kelompok perlakuan tidak menunjukkan peningkatan yang signifikan. Hal ini tidak sejalan dengan penelitian sebelumnya dimana terjadi peningkatan signifikan pada kadar asam urat tikus setelah diberikan otak kambing. ${ }^{25}$ Hal ini diduga karena tikus mempunyai enzim uricase sehingga asam urat dapat diubah langsung menjadi allantoin yang sangat larut dalam air sehingga dapat dikeluarkan melalui urin. ${ }^{26}$ Selain itu pada penelitian sebelumnya otak kambing mentah diberikan dengan dicampur pada pakan standar. Namun pada penelitian ini otak kambing telah mengalami proses perebusan lalu diberikan dengan cara sonde agar dosis yang diberikan pada tikus bisa lebih tepat. Perebusan bertujuan agar tekstur otak kambing lebih lembut dan lebih memudahkan untuk disonde. Proses perebusan inilah yang diduga mempengaruhi kandungan purin karena larutnya purin dalam air sehingga kadar asam urat tidak meningkat.

Peningkatan asam urat diharapkan dapat menyebabkan keadaan inflamasi yang ditandai dengan peningkatan jumlah leukosit. Meskipun kadar asam urat tidak mengalami peningkatan, namun jumlah leukosit setelah pemberian otak kambing menunjukkan peningkatan yang signifikan. Peningkatan jumlah leukosit tidak berhubungan dengan kadar asam urat. Peningkatan jumlah leukosit diduga karena kandungan lain yang terdapat pada otak kambing. Selain tinggi purin, otak kambing juga mengandung kolesterol yang cukup tinggi dibandingkan dengan bagian tubuh lain dan dibandingkan dengan hewan lain seperti ayam dan sapi. ${ }^{27}$ Makanan tinggi lemak dapat berakibat pada mekanisme yang meningkatkan aktifitas inflamasi, yang menjadi kunci perkembangan aterosklerosis. ${ }^{28}$ Penelitian menyebutkan pemberian lemak menunjukkan jumlah leukosit yang lebih tinggi. ${ }^{29}$

Hiperkolesterol dapat menyebabkan pengendapan lemak yang akan menyebabkan serangkaian perubahan biologis. ${ }^{30}$ Bioavabilitas nitrit oksida (NO) akan mengalami penurunan yang akan memicu endotel mengeluarkan agen anti inflamasi, salah satunya leukosit. ${ }^{31}$ Leukosit akan bergulir dan menempel pada dinding endotel hingga terjadi remodeling endotel. ${ }^{31}$ Selanjutnya monosit akan berdiferensiasi menjadi makrofag. ${ }^{30,31}$ Makrofag akan menangkap dan menimbun lemak lalu membentuk sel busa. ${ }^{30,31}$ Sel busa dapat menyebabkan lesi yang dapat berkembang menjadi plak. ${ }^{30,31}$ Terdapat 2 jenis plak, yaitu plak yang stabil dan tidak stabil. ${ }^{30}$ Plak yang tidak stabil lebih mudah ruptur. ${ }^{30}$

Pemberian seduhan daun kelor diharapkan dapat menurunkan jumlah leukosit karena efek anti inflamasi yang dimiliiki daun kelor. Namun penurunan jumlah leukosit yang signifikan juga terjadi pada kelompok kontrol yang tidak diberikan seduhan daun kelor. Hal ini diduga karena tikus sudah tidak mendapat otak kambing sehingga tidak ada yang memacu respon inflamasi dan metabolisme sudah kembali normal. Selain itu leukosit merupakan penanda inflamasi akut yang mulai meningkat sejak 2 jam dan mencapai puncak 2-4 hari. Leukosit akan kembali normal dalam waktu 1 minggu. Penurunan jumlah leukosit pada kelompok perlakuan yang lebih besar diduga karena kandungan kuersetin dan vitamin $\mathrm{C}$ yang terdapat pada daun kelor. 
Kuersetin merupakan flavonoid yang termasuk dalam kelompok flavonol. ${ }^{32}$ Kuersetin dilaporkan memiliki efek anti inflamasi. ${ }^{32}$ Kuersetin dapat menurunkan imobilisasi dan adhesi leukosit ke dinding endotel. ${ }^{32,33}$ Selain itu kersetin dan vitamin $\mathrm{C}$ juga bertindak sebagai antioksidan yang dapat menghambat oksidasi Low Density Lipoprotein (oxLDL) yang dianggap sebagai pemicu proses inflamasi pada jaringan endotel dan inisiator aterosklerosis. ${ }^{34}$

\section{SIMPULAN}

Pemberian otak kambing tidak dapat menaikkan kadar asam urat, namun dapat meningkatkan jumlah leukosit pada tikus. Kadar asam urat tikus kontrol setelah pemberian otak kambing mengalami penurunan signifikan $(p=0,002)$, sedangkan pada kelompok perlakuan menunjukkan peningkatan rerata namun tidak signifikan $(p=0,83)$. Jumlah leukosit pada kedua kelompok menunjukkan perbedaan yang signifikan $(p=0,005$ dan $p=0,015)$. Tidak ada hubungan antara kadar asam urat dan jumlah leukosit $(p=0,65)$. Pemberian seduhan daun kelor dapat menurunkan jumlah leukosit pada tikus. Jumlah leukosit setelah pemberian seduhan daun kelor menunjukkan perbedaan yang signifikan pada kelompok perlakuan $(p=0,008)$ dengan penurunan rerata yang lebih besar dibandingkan kelompok kontrol $(p=0,004)$.

\section{SARAN}

Penggunaan kalium oksonat dapat digunakan untuk menghambat kerja enzim urikase sehingga dapat terjadi peningkatan asam urat dengan cepat. Pemeriksaan kadar kolesterol perlu dilakukan untuk melihat peningkatan dan penurunan kadar kolesterol sebelum dan sesudah perlakuan. Uji kandungan daun kelor juga perlu dilakukan agar mendapatkan dosis yang optimal. Penelitian lebih lanjut diperlukan untuk melihat daya terima pemberian seduhan daun kelor pada manusia.

\section{DAFTAR PUSTAKA}

1. Mehta A, Hoffbrand V. Haematology at a Glance. Third Edit. West Sussex: Wiley-Blackwell; 2009. Chapter 3, Normal Blood Cells II: Granulocytes, Monocytes and the Reticuloendothelial System; p.12-3.

2. Zukesti Effendi. Peranan Leukosit Sebagai Anti Inflamasi Alergik Dalam Tubuh. Histologi. 2003:18.

3. Abramson N, Melton B, Regional B. Leukocytosis : Basics of Clinical Assessment. American Family Physician. 2000; 62(9) : 2053-60.
4. Abbas AK, Lichtman AH. Basic Immunology: Funtions and Disorders of the Immune System. Third Edit. Philadelphia: Saunders Elsevier; 2009.

5. Kumar V, Verma A, Ahmed D, Sachan AK, Anwar F, Mujeeb M. Fostered Antiarthritic Upshot of Moringa Oleifera Lam. Stem Bark Extract in Diversely Induced Arthritis in Wistar Rats With Plausible Mechanism. International Journal of Pharmaceutical Sciences and Research. 2013; 4(10): 3894-901.

6. Ngestiningsih D, Hadi S. Ekstrak Herbal (Daun Salam, Jintan Hitam, Daun Seledri) dan Kadar IL-6 Plasma Penderita Hiperurisemia. Media Medika Indonesiana. 2011; 45: 113-17.

7. Ruggiero et al. Uric Acid and Inflammatory Markers. European heart journal. 2006; 27(10): 1174-81.

8. Meisinger C, Koenig W, Baumert J, Döring A. Uric Acid Levels Are Associated With All-Cause And Cardiovascular Disease Mortality Independent of Systemic Inflammation in Men From the General Population. Arteriosclerosis, thrombosis, and vascular biology. 2008; 28(6): 1186-92.

9. Kocaman et al. Independent Relationship of Serum Uric Acid Levels with Leukocytes and Coronary Atherosclerotic Burden. Nutrition, metabolism, and cardiovascular diseases: Nutrition, Metabolism and Cardiovascular Diseases. 2009; 19(10): 72935.

10. Kono H, Chen C, Ontiveros F, Rock KL. Uric Acid Promotes an Acute Inflammatory Response to Sterile Cell Death in Mice. The Journal of Clinical Investigation. 2010; 120(6): 1939-49.

11. Coller BS. Leukocytosis and Ischemic Vascular Disease Morbidity and Mortality: Is It Time to Intervene?. Arteriosclerosis, Thrombosis, and Vascular Biology. 2005; 25(4): 658-70.

12. Woollard KJ, Geissmann F. Monocytes in Atherosclerosis: Subsets and Functions. Nature Review Cardiology. 2010; 7: 77-86.

13. Farooq F, Rai M, Tiwari A, Khan AA, Farooq S. Medicinal properties of Moringa oleifera: An overview of promising healer. Journal of Medicinal Plants Research. 2012; 6(27): 4368-4374.

14. Anwar F, Latif S, Ashraf M, Gilani AH. Moringa oleifera: A Food Plant with Multiple Medicinal Uses. Phytotherapy Research. 2007; 21: 17-25.

15. Rajan AP, Santhalia S, Sciences B, Nadu T. Comparative analysis of preservation techniques on Moringa oleifera. International Journal of Agricultural and Food Science. 2011; 1(2): 12-22.

16. Charoensin S. Antioxidant and anticancer activities of Moringa oleifera leaves. Journal of Medicinal Plants Research. 2014; 8(7): 318-25.

17. Witt KA. The Nutrient Content of Moringa oleifera Leaves. Messiah College Department of Nutrition and Dietetics

18. Mcknight M, Allen J, Waterman JT, Hurley S, Idassi J, Minor RC. Moringa Tea Blocks Acute Lung Inflammation Induced By Swine 
Confinement Dust Through a Mechanism Involving Tnf-Ît Expression, C-Jun N-Terminal Kinase Activation and Neutrophil Regulation. American Journal of Immunology. 2014; 10(2): 73-87.

19. Madukwe EU, Ugwuoke AL, Ezeugwu JO. Effectiveness of dry Moringa oleifera leaf powder in treatment of anaemia. International Journal of Medicine and Medical Sciences. 2013;5(5):226228.

20. Keiko Morikawa. Mitsuko Nonakaa. Misa Naraharaa. Ikuko Torii. Kiichiro Kawaguchic. Takafumi Yoshikawac. Yoshio Kumazawad. Shigeru Morikawa. Inhibitory effect of quercetin on carrageenan-induced inflammation in rats. Life Sciences. 2003;74(6):709-721.

21. Marcolin E, San-miguel B, Vallejo D, Tieppo J, Marroni N. Quercetin Treatment Ameliorates Inflammation and Fibrosis in Mice with Steatohepatitis. 2012;(12):3-4.

22. Wang C, Pan Y, Zhang Q-Y, Wang F-M, Kong LD. Quercetin and allopurinol ameliorate kidney injury in STZ-treated rats with regulation of renal NLRP3 inflammasome activation and lipid accumulation. PloS one. 2012;7(6): 382-385.

23. Mongi S, Mahfoud M, Amel B, Kamel J, Abdelfattah EF. Protective Effects Of Vitamin C Against Haematological and Biochemical Toxicity Induced by Deltamethrin in Male Wistar Rats. Ecotoxicology and environmental safety. 2011;74(6): 1765-9.

24. Tahir I. Arti Penting Kalibrasi Pada Proses Pengukuran Analitik: Aplikasi Pada Penggunaan PHmeter Dan Spektrofotometer Uv-Vis [thesis]. Yogyakarta: Universitas Gajah Mada; 2008

25. Pribadi FW, Ernawati DA. Efek Catechin Terhadap Kadar Asam Urat , C - Reactive Protein (CRP) Dan Malondialdehid (MDA) Darah Tikus Putih (Rattus Norvegicus) Hiperurisemia. Mandala of Health. 2010; 4(1): 39-46.

26. Nurochman S, Widada ST, Arisandi D. Perbedaan Kadar Asam Urat Sebelum dan Sesudah Pemberian Jeroan pada Tikus Putih [thesis]. Yogyakarta: Stikes Guna Bangsa; 2008.

27. Bakar U. Analisa Kadar Kolesterol Dalam Otak, Hati, dan Usus Hewan yang Dikonsumsi Masyarakat Kodya Padang [thesis]. Padang: Institut Keguruan dan Ilmu Pendidikan Padang; 1993.

28. Lundman et al. High-fat Meal is Accompanied by Increased Plasma Interleukin-6 Concentrations. Nutrition, Metabolism \& Cardiovascular Diseases. 2007; 17: 195-202

29. Witradharma TW, Lipoeto NI, Asri A. Pengaruh Konsumsi Berbagai Jenis Asam Lemak terhadap Indikator Kejadian Aterogenesis Pada Tikus Jantan Strain Wistar [thesis]. Padang: Universitas Andalas; 2011.

30. Fan J, Watanabe T. Inflammatory Reactions in the Pathogenesis of Atherosclerosis. Journal of Atherosclerosis and Trombosis. 2003; 10(2): 63-71.
31. Moore KJ, Tabas I. Macrophages in the Pathogenesis of Atherosclerosis. Cell. 2011; 145(3): 341-355.

32. Lakhanpal P, Rai DK. Quercetin: A Versatile Flavonoid. Internet Journal of Medical Update. 2007; 2(2): 22-37.

33. Nijveldt RJ, Nood E, Hoorn DEC, Boelens PG, Norren K, Leeuwen PAM. Flavonoids: A Review of Probable Mechanisms of Action and Potential Applications. The American Journal of Clinical Nutrition. 2001;74:418-425.

34. Ashor AW, Lara J, Mathers JC, Siervo M. Effect of Vitamin C on Endothelial Function in Health and Disease: a ystematic review and meta-analysis of randomised controlled trials. Atherosclerosis. 2014; 235(1): 9-20. 